\title{
Przeżycia chorych na drobnokomórkowego raka płuca leczonych napromienianiem w latach 2003-2006 w Samodzielnym Publicznym Zakładzie Opieki Zdrowotnej Ministerstwa Spraw Wewnętrznych z Warmińsko-Mazurskim Centrum Onkologii w Olsztynie
}

\author{
Karolina Osowiecka ${ }^{1}$, Monika Rucińska ${ }^{1,2}$, \\ Małgorzata Suszko-Każarnowicz ${ }^{3}$, \\ Sergiusz Nawrocki ${ }^{1,2,4}$
}

Wstęp. Drobnokomórkowy rak płuca (DRP) jest jednym z najgorzej rokujących nowotworów złośliwych ze względu na szybki miejscowy rozwój choroby i wczesne powstawanie przerzutów odległych. Celem analizy była ocena skuteczności leczenia chorych na DRP w Samodzielnym Publicznym Zakładzie Opieki Zdrowotnej Ministerstwa Spraw Wewnętrznych z Warmińsko-Mazurskim Centrum Onkologii w Olsztynie (SP ZOZ MSW z W-MCO w Olsztynie), prowadzonego w latach 2003-2006 (pierwsze 4 lata działalności ośrodka).

Materiał i metody. Analizą objęto wszystkich chorych (202) leczonych napromienianiem na DRP w latach 2003-2006. W tej grupie znaleźli się pacjenci z postacią LD i ED, leczeni radykalnie i paliatywnie. Przeżycia całkowite chorych oszacowano za pomocą metody Kaplana-Meiera. Przeżycia w podgrupach porównano przy użyciu testu log-rank (wyniki mają ograniczoną wartość ze względu na retrospektywny charakter analizy).

Wyniki. 2- i 5-letnie przeżycia całkowite wszystkich 202 chorych wyniosły odpowiednio 25\% i 10\% (mediana przeżyć 11 miesięcy). 2- i 5-letnie przeżycia całkowite pacjentów z postacią LD DRP wyniosły odpowiednio 36\% i 15\% (mediana przeżyć 17 miesięcy). Nikt z pacjentów z postacią ED DRP nie przeżył 5 lat, 2 lata przeżył 1 pacjent (mediana przeżyć 3,3 miesiąca). 2- i 5-letnie przeżycia całkowite pacjentów otrzymujących radiochemioterapię jednoczasową i sekwencyjną wyniosły odpowiednio 44\% vs 31\% i 17\% vs 16\% (p=0,38). 2- i 5-letnie przeżycia całkowite pacjentów leczonych radykalnie, u których rozpoczęto radioterapię z 1 lub 2 kursem chemioterapii, z 3-6 kursem chemioterapii lub po zakończeniu chemioterapii wyniosły odpowiednio $48 \%$ vs 42\% vs 31\% i 24\% vs 14\% vs 16\% (różnice pomiędzy tymi grupami nie są istotne statystycznie). Nie wykazano różnic w przeżyciach całkowitych 2- i 5-letnich pomiędzy pacjentami, którzy otrzymali radioterapię 2 razy dziennie i raz dziennie $(p=0,87)$. Kobiety rokują lepiej niż mężczyźni. 2- i 5-letnie przeżycia całkowite kobiet wyniosły odpowiednio 54\% i 24\%, a mężczyzn - 32\% i 13\% ( $p=0,016)$. 2-i 5-letnie przeżycia całkowite pacjentów leczonych radykalnie, którzy otrzymali PCl, wyniosły 58\% i 18\%, a pacjentów niepoddanych $\mathrm{PCl}-21 \%$ i $12 \%(p=0,00004)$.

Podsumowanie. W porównaniu z leczeniem sekwencyjnym przeżycia chorych leczonych radykalnie (postać LD) były nieco dłuższe, jeżeli radioterapię stosowano jednoczasowo z chemioterapią (brak znamienności statystycznej). Zauważono tendencję do poprawy przeżyć w przypadku kojarzenia radioterapii z chemioterapią na początku ca-

${ }^{1}$ Zakład i Oddział Radioterapii, Samodzielny Publiczny Zakład Opieki Zdrowotnej Ministerstwa Spraw Wewnętrznych z Warmińsko-Mazurskim Centrum Onkologii w Olsztynie

${ }^{2}$ Katedra Onkologii, Wydział Nauk Medycznych, Uniwersytet Warmińsko-Mazurski w Olsztynie

${ }^{3}$ Oddział Onkologii i Chemioterapii Nowotworów Płuc, Samodzielny Publiczny Zespół Gruźlicy i Chorób Płuc w Olsztynie ${ }^{4}$ Katedra Onkologii i Radioterapii Śląskiego Uniwersytetu Medycznego, SPSK 5 w Katowicach 
łego cyklu leczenia. Wyniki leczenia uzyskane w ciągu pierwszych 4 lat działalności ośrodka SP ZOZ MSW z W-MCO w Olsztynie nie odbiegały od publikowanych wyników badań klinicznych.

\section{Survival of patients treated with radiation for small-cell lung cancer in the Hospital of the Ministry of Interior with Warmia and Mazury Oncology Center in Olsztyn between 2003 and 2006}

Introduction. Small-cell lung cancer (SCLC) is one of the cancers with the worst prognosis because of its fast growth and early metastases. The aim of this study was the estimation of treatment effectiveness of patients treated with small-cell lung cancer in the Hospital of the Ministry of Interior with Warmia and Mazury Oncology Center in Olsztyn between 2003 and 2006 (the initial 4 years of Centre activity).

Material and methods. The analysis included all patients (202) treated with radiation for SCLC between 2003 and 2006. Patients in this group (both limited disease-LD and extensive disease-ED) were treated with radical or palliative radiotherapy. The Kaplan-Meier method was used to estimate overall survival. Differences in survival of subgroups were evaluated using the log-rank test. Results have limited value due to retrospective analysis.

Results. Overall 2- and 5-year overall survival (OS) of all 202 patients was respectively $25 \%$ and $10 \%$ (median 11 months). 2- and 5-year OS of patients with LD SCLC was respectively $36 \%$ and $15 \%$ (median 17 months). None of the patients with ED SCLC survived 5 years but one patient survived 2 years (median 3.3 months). 2- and 5-year OS of patients who received concurrent and sequential chemoradiotherapy was $44 \%$ vs $31 \%$ and $17 \%$ vs $16 \%$ ( $p=0.38) .2-$ and 5-year OS of patients treated radically, who began radiotherapy with 1 or 2 cycle of chemotherapy, with 3-6 cycle of chemotherapy or after chemotherapy was $48 \%$ vs $42 \%$ vs $31 \%$ and $24 \%$ vs $14 \%$ vs $16 \%$ (differences between groups were not statistically significant). There were no differences between 2- and 5-year OS of patients treated with radiation administered twice daily and once daily $(p=0.87)$. Survival of women was better than men. 2- and 5-year OS of women was appropriately $54 \%$ and $24 \%$ and OS of men was $32 \%$ and $13 \%(p=0.016)$. 2 - and 5 -year OS of patients treated radically, who received $\mathrm{PCI}$ was $58 \%$ and $18 \%$ and OS of patients who did not receive $\mathrm{PCI}$ was $21 \%$ and $12 \%$ $(p=0.00004)$.

Conclusions. Survival of patients (LD SCLC) who received concurrent chemoradiotherapy was statistically better than patients who received sequential chemoradiotherapy (statistically non-significant). There was a tendency towards better survival if radiotherapy was given with initial cycles of chemotherapy. These results of treatment in the Hospital of the Ministry of Interior with Warmia and Mazury Oncology Center in Olsztyn which were obtained during the initial four years of Centre activity did not differ from published results of clinical trials.

NOWOTWORY Journal of Oncology 2013; 63, 5: 395-402

Słowa kluczowe: DRP, radiochemioterapia jednoczasowa i sekwencyjna, PCI, 2-letnie i 5-letnie przeżycia całkowite Key words: SCLC, concurrent and sequential chemoradiotherapy, $\mathrm{PCl}, 2$ - and 5-year overall survival

\section{Wstęp}

W Polsce rak płuca jest najczęstszym nowotworem złośliwym u mężczyzn i drugim co do częstości występowania u kobiet (stanowi 21,1\% wszystkich zachorowań na nowotwory złośliwe u mężczyzn i 8,6\% u kobiet). Rak płuca jest obecnie najczęstszą przyczyną zgonów z powodu nowotworów u obu płci (stanowi 31,2\% wszystkich zgonów z powodu nowotworów złośliwych u mężczyzn i 15,1\% u kobiet) [1]. Obecnie około 15-20\% wszystkich nowotworów złośliwych płuc stanowi rak drobnokomórkowy (DRP). Rokowanie w drobnokomórkowym raku płuca jest złe ze względu na szybki miejscowy rozwój choroby i wczesne powstawanie przerzutów odległych [2, 3]. Nowoczesne skojarzone leczenie pozwala na uzyskanie całkowitych przeżyć dwuletnich rzędu $20-40 \%$ w stadium choroby ograniczonej i 10-15\% w postaci rozsianej. Niezależnie od stadium zaawansowania w momencie rozpoznania wieloletnie przeżycia dotyczą jedynie pojedynczych chorych.

Celem niniejszej analizy była ocena skuteczności leczenia chorych na drobnokomórkowego raka płuca w Samodzielnym Publicznym Zakładzie Opieki Zdrowotnej Ministerstwa Spraw Wewnętrznych z Warmińsko-Mazurskim Centrum Onkologii w Olsztynie (SP ZOZ MSW z W-MCO w Olsztynie), prowadzonego w latach 2003-2006 (pierwsze 4 lata działalności ośrodka).

\section{Materiał i metody}

Analizą objęto wszystkich chorych z rozpoznaniem drobnokomórkowego raka płuca leczonych napromienianiem w SP ZOZ MSW z W-MCO w Olsztynie w latach 2003- 

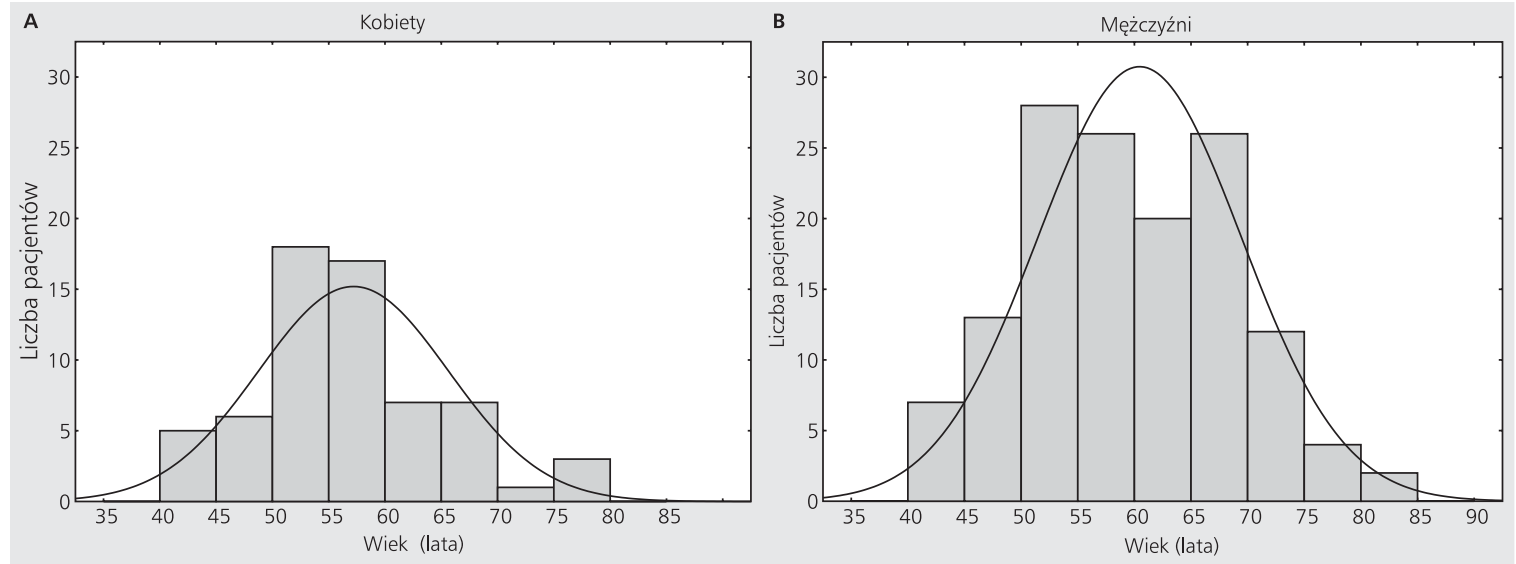

Rycina 1. Pacjenci leczeni napromienianiem z powodu DRP w SP ZOZ MSW z W-MCO w Olsztynie w latach 2003-2006 [A — kobiety (64); B - mężczyźni (138)]

-2006. W tej grupie znaleźli się pacjenci zarówno z postacią ograniczoną (LD — limited disease), jak i z postacią uogólnioną (ED - extensive disease), leczeni radykalnie i paliatywnie.

Baza danych Lantis wykorzystywana w Zakładzie Radioterapii SP ZOZ MSW z W-MCO w Olsztynie posłużyła do wygenerowania listy chorych. Dane o śmierci pacjentów uzyskano z Warmińsko-Mazurskiego Rejestru Nowotworów w Olsztynie oraz z Centrum Personalizacji Dokumentów Ministerstwa Spraw Wewnętrznych Wydziału Udostępniania Danych w Warszawie. Pozostałe dane wykorzystane do analizy pochodziły z dokumentacji medycznej (historia choroby) oraz z bazy danych Lantis. Bazę danych sporządzono w programie STATISTICA (wersja 10; 2012r.). Za pomocą tego oprogramowania przeprowadzono analizy przeżyć pacjentów mierzone od daty rozpoczęcia leczenia (dla pacjentów leczonych radykalnie - od pierwszego dnia chemioterapii, dla pacjentów leczonych paliatywnie — od pierwszego dnia radioterapii) do daty ostatniej obserwacji (śmierci). Analiza przeżycia została przeprowadzona z wykorzystaniem metody Kaplana-Meiera, a istotność statystyczna różnic pomiędzy grupami była oceniana testem log-rank. Za statystycznie znamienne przyjęto wartości $\mathrm{p} \leq 0,05$.

\section{Wyniki}

W latach 2003-2006 w SP ZOZ MSW zW-MCO w Olsztynie leczono napromienianiem 202 chorych na drobnokomórkowego raka płuca. W analizowanej grupie były 64 kobiety (31,7\%) i 138 mężczyzn (68,3\%). Rozpiętość wieku leczonych pacjentów była duża (41-82 lata). Kobiety były nieco młodsze niż mężczyźni (kobiety: 41-80 lat, średnia wieku 57 lat; mediana 56 lat, odchylenie standardowe SD = 8,4 lat; mężczyźni: 43-82 lata, średnia wieku 60 lat; mediana 59 lat, odchylenie standardowe SD = 9 lat) (ryc. 1A i B).

Prawie 2/3 chorych z rozpoznaniem DRP leczonych w analizowanym okresie (126 pacjentów, 62,4\%) otrzyma-
Tabela I. Sposób leczenia (202 pacjentów)

\begin{tabular}{lcc}
\hline Sposób leczenia & Liczba & $\%$ \\
\hline Leczenie radykalne & 126 & 62,4 \\
Radiochemioterapia & 123 & 97,6 \\
Pooperacyjna radiochemioterapia & 3 & 2,4 \\
Radiochemioterapia jednoczasowa & 77 & 61,1 \\
Radiochemioterapia sekwencyjna & 49 & 38,9 \\
PCI & 66 & 52,4 \\
bez PCl & 60 & 47,6 \\
Radioterapia paliatywna & 76 & 37,6 \\
\hline
\end{tabular}

ło leczenie z intencją radykalną (tab. I). Nie zaobserwowano różnicy w odsetkach leczonych radykalnie zależnej od płci. 41 pacjentek z 64 kobiet chorych na DRP $(64,1 \%)$ i 85 pacjentów ze 138 mężczyzn chorych na DRP $(61,6 \%)$ poddanych zostało napromienianiu $z$ intencją radykalną.

U 2/3 chorych na DRP (138 pacjentów; 68,3\%) stwierdzono chorobę w stadium LD, u 64 pacjentów (31,7\%) — w stadium ED. 126 pacjentów ze 138 chorych w stadium zaawansowania LD (91,3\%) otrzymało radykalną radiochemioterapię. Pozostałych 12 pacjentów (8,7\%) w stadium zaawansowania LD otrzymało radioterapię paliatywną: 1 pacjent odmówił pierwotnie leczenia, a następnie otrzymał radioterapię $z$ powodu progresji miejscowej, 1 pacjent nie otrzymał zaplanowanej po chemioterapii radioterapii radykalnej z powodu złego stanu ogólnego, u 1 pacjenta odstąpiono zarówno od chemioterapii, jak i radykalnej radioterapii ze względu na stan ogólny, 9 pacjentów otrzymało jedynie radioterapię paliatywną z powodu progresji choroby $w$ trakcie lub bezpośrednio po zakończeniu chemioterapii (8-30 Gy w 1-10 frakcjach) (tab. II). 3 pacjentów (2,4\%) było pierwotnie operowanych, a następnie otrzymało radiochemioterapię. 
Tabela II. Sposób leczenia pacjentów w stadium zaawansowania LD i ED

\begin{tabular}{lcc}
\hline Pacjenci w stadium zaawansowania & Liczba & $\%$ \\
\hline LD & 138 & 68,3 \\
leczeni radykalnie & 126 & 91,3 \\
leczeni paliatywnie & 12 & 8,7 \\
ED & 64 & 31,7 \\
\hline
\end{tabular}

\section{Radiochemioterapia}

Jako leczenie radykalne stosowano standardowo radiochemioterapię w różnych sekwencjach. Radioterapię przeprowadzono przy użyciu fotonów o energii $6 \mathrm{MV}$ uzyskanych w akceleratorze liniowym. Stosowano planowanie leczenia 3D. 32 pacjentów leczonych radykalnie (25\% wszystkich pacjentów leczonych radykalnie) otrzymało 45 Gy w 30 frakcjach po 1,5 Gy dwa razy dziennie (u 1 pacjenta zastosowano dodatkowo boost 18 Gy po 2 Gy). 14 pacjentów (11\%) otrzymało 54 Gy (11 pacjentów w 30 frakcjach po 1,8 Gy i 3 pacjentów w 27 frakcjach po 2 Gy). 69 pacjentów (55\%) otrzymało 40-45 Gy w dawce frakcyjnej 1,8-2 Gy i boost 6-16 Gy po 1,8-2,5 Gy (sumarycznie 50,4-59 Gy). 6 pacjentów (15\%) otrzymało 41,4-45 Gy po 1,8-2 Gy. 2 pacjentów otrzymało 36 Gy w 12 frakcjach po 3 Gy. 1 pacjent otrzymał 66 Gy w 33 frakcjach po 2 Gy ze względu na postać mieszaną raka (rak drobnokomórkowy i niedrobnokomórkowy). U 2 pacjentów leczonych z intencją radykalną odstąpiono od kontynuacji leczenia z powodu powikłań (po dawce 23,4 Gy i po 34,2 Gy). Ponad połowa pacjentów leczonych radykalnie (77 pacjentów, 61,1\%) otrzymała radiochemioterapię (cisplatyna i etopozyd) jednoczasową (minimum jeden kurs chemioterapii podany równocześnie z radioterapią). U pozostałych 49 pacjentów $(38,9 \%)$ zastosowano radiochemioterapię sekwencyjną (1-6 kursów chemioterapii podawanych przed rozpoczęciem radioterapii, a następnie - po zakończeniu radioterapii - kontynuacja chemioterapii do sumarycznej liczby 5-6 kursów) (tab. I). Połowa pacjentów otrzymujących radiochemioterapię równoczasową rozpoczęła napromienianiez3. lub4.kursem, a 1/3 pacjentów-z1.lub 2. kursem chemioterapii (tab. III). Decyzja o wyborze sposobu kojarzenia chemioterapii i radioterapii w większości przypadków wynikała ze względów organizacyjnych (chorzy trafiali do ośrodka radioterapii nierzadko już po rozpoczęciu leczenia chemioterapią), a nie medycznych.

Całkowity czas trwania radiochemioterapii (czas od początku chemioterapii do zakończenia radioterapii) wyniósł 2,7-44,3 tygodnia (mediana 13,7 tygodnia, średni czas 14,5 tygodnia, odchylenie standardowe 8,4 tygodnia).

$\mathrm{U}$ połowy pacjentów leczonych $\mathrm{z}$ intencją radykalną $(52,4 \%)$ zastosowano profilaktyczne napromienianie mózgowia (PCI) w dawce 24 lub 30 Gy w 8 lub 10 frakcjach po 3 Gy, w tym 1 pacjent odmówił przyjęcia ostatniej frakcji, wobec czego otrzymał 21 Gy w 7 frakcjach zamiast planowa-
Tabela III. Sposób kojarzenia jednoczasowej radioterapii z chemioterapią

\begin{tabular}{lcc}
\hline Radiochemioterapia jednoczasowa & Liczba & $\%$ \\
\hline $\begin{array}{l}\text { Rozpoczęcie radioterapii z } 1 \\
\text { lub 2 kursem chemioterapii }\end{array}$ & 25 & 32,5 \\
$\begin{array}{l}\text { Rozpoczęcie radioterapii z 3 } \\
\text { lub 4 kursem chemioterapii }\end{array}$ & 41 & 53,2 \\
$\begin{array}{l}\text { Rozpoczęcie radioterapii z 5 I } \\
\text { ub 6 kursem chemioterapii }\end{array}$ & 11 & 14,3 \\
\hline
\end{tabular}

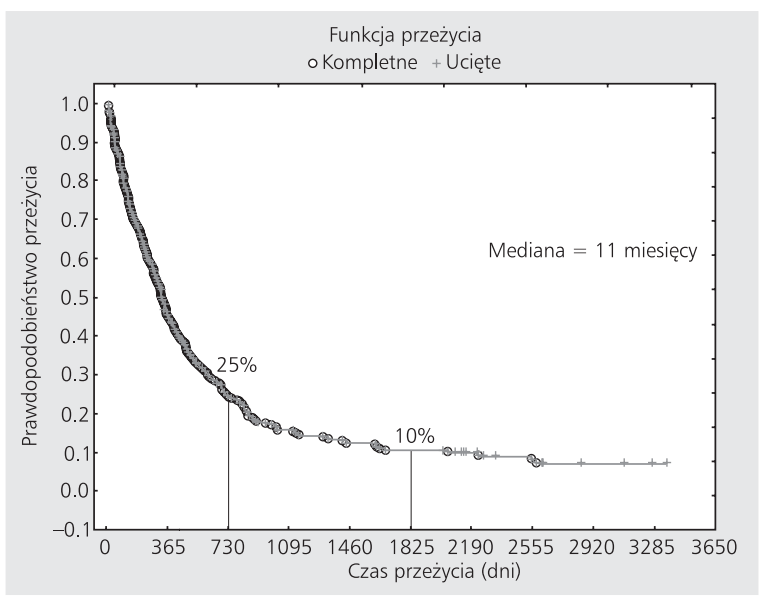

Rycina 2. Krzywa przeżycia całkowitego wszystkich 202 pacjentów

nych 24 Gy (tab. I). W omawianym okresie PCl otrzymywali jedynie pacjenci, u których uzyskano całkowitą remisję po radiochemioterapii.

\section{Analiza przeżyć}

Spośród 202 pacjentów leczonych z powodu DRP w latach 2003-2006 w tutejszym ośrodku 185 pacjentów zmarło, a 17 żyje nadal. Wszystkie żyjące osoby to pacjenci z postacią ograniczoną choroby. 2-letnie przeżycia całkowite (OS) dla wszystkich chorych wynosiły 25\%, 5-letnie przeżycia całkowite wynosiły 10\% (mediana przeżyć 11 miesięcy) (ryc. 2). 2-letnie przeżycia całkowite pacjentów z postacią ograniczoną DRP wynosiły 36\%, a 5-letnie przeżycia całkowite wynosiły 15\% (mediana przeżyć 17 miesięcy). Spośród 64 pacjentów z postacią uogólnioną DRP nikt nie przeżył 5 lat, 2 lata przeżył 1 pacjent (1,6\%) (mediana przeżyć 3,3 miesiąca) (ryc. 3).

Przeprowadzono analizę porównawczą dwóch grup pacjentów, którzy otrzymali radykalną radiochemioterapię, różniących się sposobem kojarzenia radioterapii z chemioterapią. Nie wykazano różnic w przeżyciach 5-letnich pomiędzy grupą pacjentów otrzymujących chemioterapię równocześnie z radioterapią i grupą chorych leczonych sekwencyjnie, które wyniosły odpowiednio 17\% (13 pacjentów) i 16\% (8 pacjentów). Zaobserwowano natomiast dłuższe przeżycia 2-letnie i medianę przeżyć u pacjentów leczonych równoczasowo. 2 lata przeżyło 44\% pacjentów 


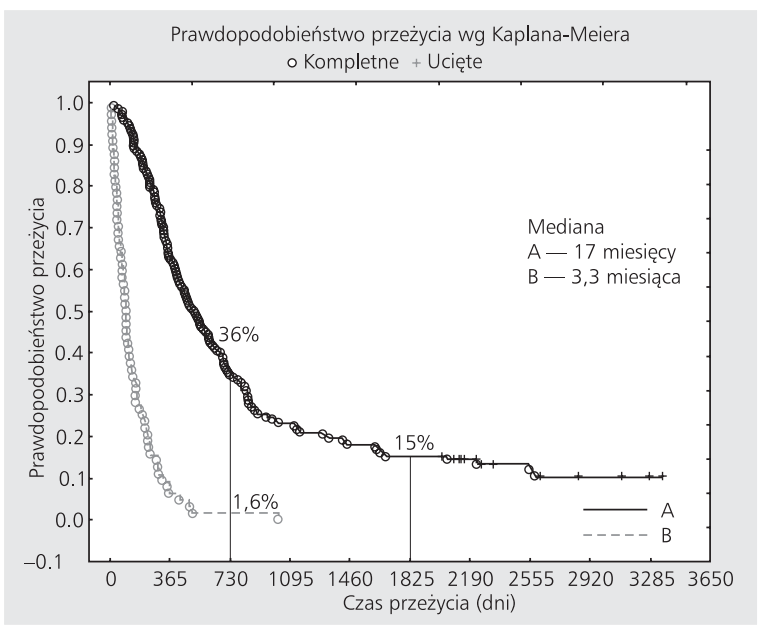

Rycina 3. Krzywe przeżycia całkowitego pacjentów w stadium zaawansowania LD i ED (A - 138 pacjentów z postacią LD, $B-64$ pacjentów z postacią ED)

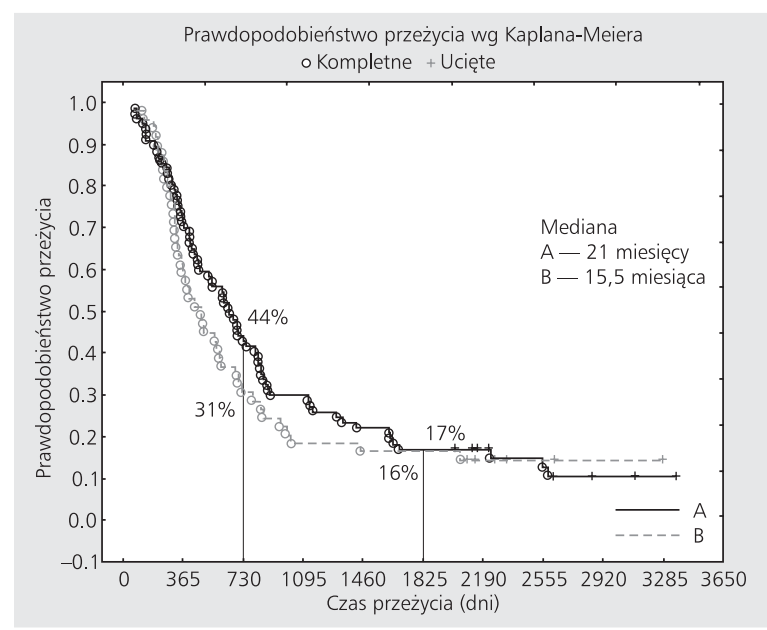

Rycina 4. Krzywe przeżycia całkowitego pacjentów w stadium LD leczonych radykalnie, różniących się sposobem kojarzenia radioterapii z chemioterapią ( $\mathrm{A}-77$ pacjentów, u których zastosowano radiochemioterapię jednoczasową, B - 49 pacjentów, u których zastosowano radiochemioterapię sekwencyjną)

otrzymujących radiochemioterapię jednoczasową (mediana przeżyć 21 miesięcy) i 31\% pacjentów leczonych sekwencyjnie (mediana przeżyć 15,5 miesiąca) (wg testu log-rank różnice pomiędzy tymi grupami nie są istotne statystycznie; $p=0,38$ ) (ryc. 4). Przeprowadzono analizę porównawczą grup pacjentów, u których rozpoczęto radioterapię z 1. lub 2. kursem chemioterapii, z 3.-6. kursem chemioterapii i po zakończeniu chemioterapii. Zarówno całkowite przeżycia 2-letnie, jak i mediana przeżyć były podobne u pacjentów, u których rozpoczynano radioterapię z 1. lub 2. kursem chemioterapii (48\%, mediana przeżyć 20 miesięcy) i u pacjentów, u których rozpoczynano radioterapię z 3.-6. kursem chemioterapii (42\%, mediana przeżyć 21 miesięcy). Zaob-

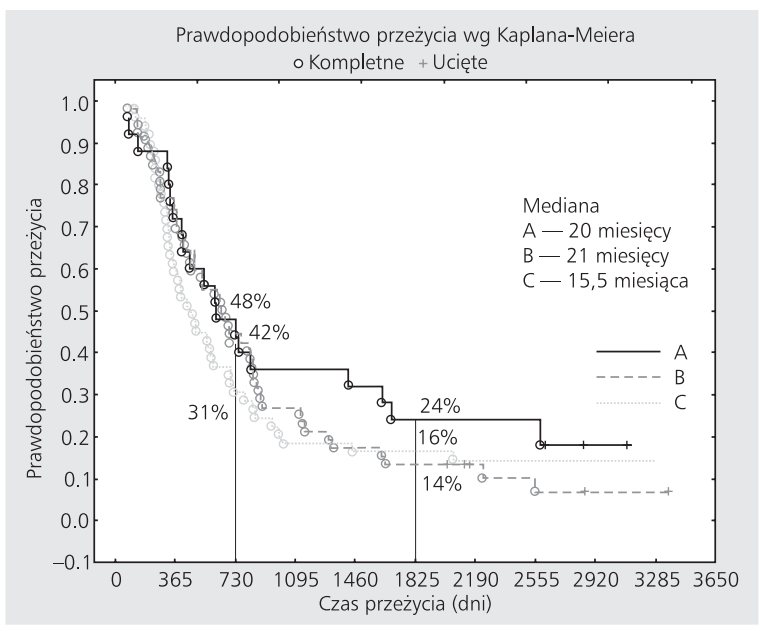

Rycina 5. Krzywe przeżycia całkowitego pacjentów leczonych radykalnie, u których rozpoczęto radioterapię z 1. lub 2. kursem chemioterapii, z 3.-6. kursem chemioterapii lub po zakończeniu chemioterapii (A - 25 pacjentów, u których rozpoczęto radioterapię $z$ 1. lub 2. kursem chemioterapii, $B-52$ pacjentów, u których rozpoczęto radioterapię z 3.-6. kursem chemioterapii, C - 49 pacjentów leczonych sekwencyjnie)

serwowano natomiast różnicę w całkowitych przeżyciach pięcioletnich. W grupie pacjentów, u których rozpoczynano radioterapię $z$ 1. lub 2 . kursem chemioterapii, 5 lat przeżyło o 1/3 więcej chorych (24\%) niż w grupie pacjentów leczonych napromienianiem z 3.-6. kursem chemioterapii (14\%) (różnice pomiędzy tymi grupami nie są jednak istotne statystycznie; $p=0,29)$. Zaobserwowano lepsze przeżycie całkowite zarówno 2-letnie jak i 5-letnie dla pacjentów otrzymujących radiochemioterapię równoczasową z 1. lub 2. kursem chemioterapii w stosunku do pacjentów leczonych sekwencyjnie (odpowiednio 48\% vs 31\% i 24\% vs 16\%, różnice pomiędzy tymi grupami nie są znamienne statystycznie; $p=0,22)$. Nie wykazano różnic w całkowitych przeżyciach 5-letnich pomiędzy pacjentami otrzymującymi radioterapię z 3.-6. kursem i sekwencyjnie, natomiast przeżycia 2-letnie były gorsze w grupie pacjentów leczonych sekwencyjnie (różnice pomiędzy tymi grupami nie są istotne statystycznie; $p=0,66$ ) (ryc. 5).

Nie wykazano różnic w całkowitych przeżyciach zarówno 2- jak i 5-letnich pomiędzy pacjentami, którzy otrzymali 45 Gy we frakcjonowaniu dwa razy dziennie, a pacjentami leczonymi konwencjonalnie (mediana przeżyć dla obu grup wyniosła 19 miesięcy) (test log-rank; $\mathrm{p}=0,87$ ) (ryc. 6).

Wykazano, iż płeć ma wpływ na przeżycia. Przeprowadzono analizę porównawczą przeżycia względem płci w grupie pacjentów leczonych radykalną radiochemioterapią. Kobiety rokowały lepiej niż mężczyźni. 5-letnie i 2-letnie przeżycia całkowite kobiet wyniosły odpowiednio 24\% i 54\% (mediana 26 miesięcy), a mężczyzn 13\% i 32\% (mediana 15 miesięcy) (wg testu log-rank różnice pomiędzy tymi grupami są istotne statystycznie; $p=0,016$ ) (ryc. 7). 


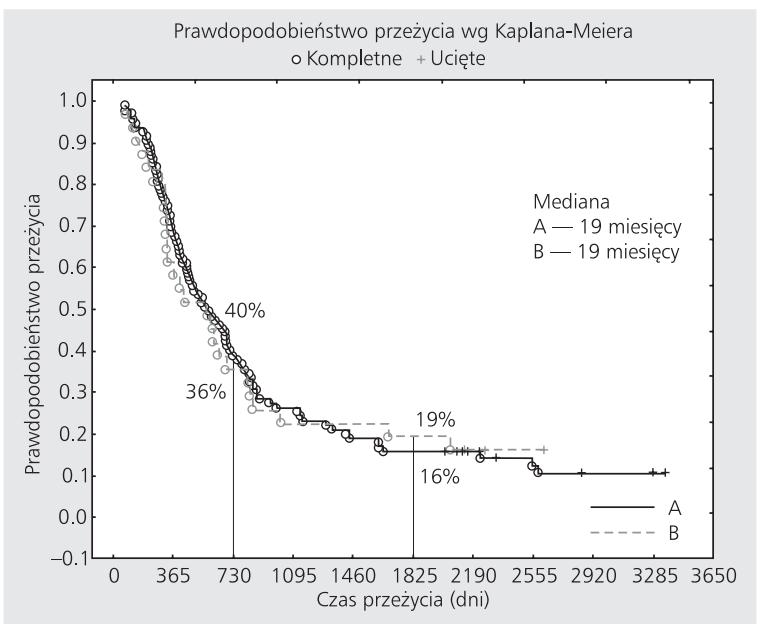

Rycina 6. Krzywe przeżycia całkowitego pacjentów leczonych z intencją radykalną, otrzymujących radioterapię 2 razy dziennie i raz dziennie ( $\mathrm{A}-95$ pacjentów napromienianych 2 razy dziennie, $B-31$ pacjentów napromienianych 1 raz dziennie)

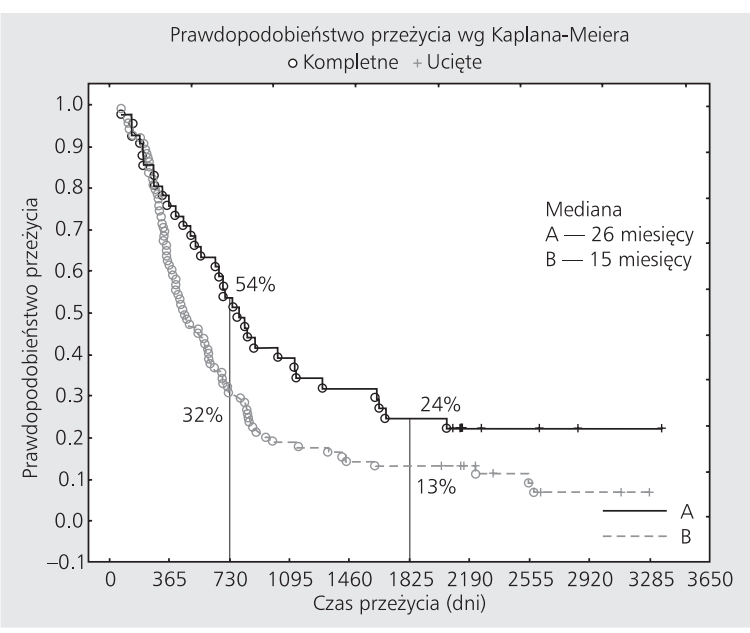

Rycina 7. Krzywe przeżycia całkowitego radykalnie leczonych pacjentów w zależności od płci ( $A-41$ kobiet, $B-85$ mężczyzn)

Ponad połowa pacjentów (58\%), którzy otrzymali profilaktyczne napromienianie mózgu, przeżyła 2 lata (mediana przeżyć 27 miesięcy); w grupie pacjentów, u których nie zastosowano PCl, 2-letnie przeżycia całkowite wyniosły $21 \%$ (mediana przeżyć 11 miesięcy). 5 lat przeżyło 18\% pacjentów, którzy otrzymali $\mathrm{PCl}$ i 12\% pacjentów niepoddanych profilaktycznemu napromienianiu mózgu (różnice pomiędzy tymi grupami wykazują znamienność statystyczną; $p=0,00004$ ) (ryc. 8).

\section{Omówienie}

Do oceny skuteczności leczenia w onkologii służy analiza wskaźników przeżyć. Dzięki rejestrom nowotworów można uzyskać dane populacyjne o zachorowaniach na nowotwory

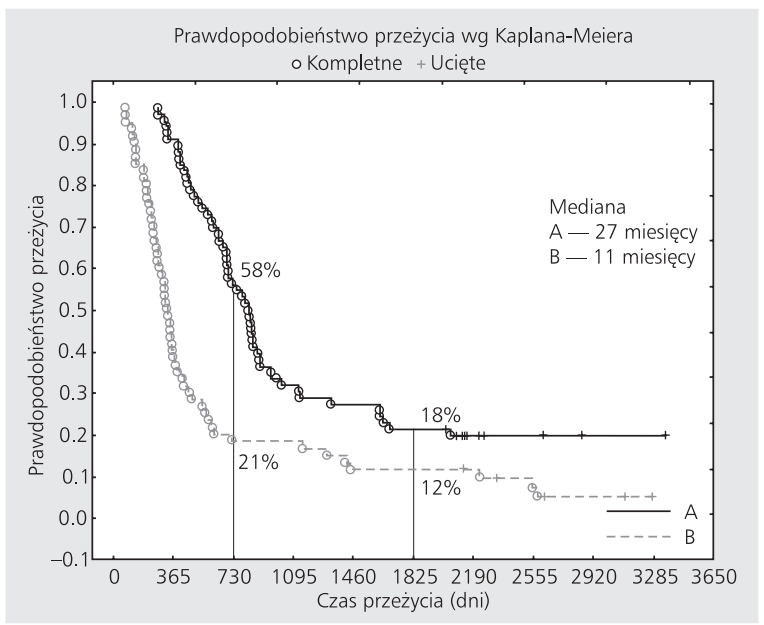

Rycina 8. Krzywe przeżycia całkowitego pacjentów w stadium LD leczonych radykalnie z- i bez $\mathrm{PCl}(\mathrm{A}-66$ pacjentów, którzy otrzymali $\mathrm{PCl} ; \mathrm{B}-60$ pacjentów, którzy nie otrzymali $\mathrm{PCI})$

złośliwe. Dane mogą pochodzić także z baz szpitalnych, aczkolwiek dotyczą one wtedy tylko osób leczonych w danym ośrodku. W Polsce rejestrowanie zachorowań na nowotwory złośliwe prowadzone jest od ponad 50 lat. W Europie wiarygodne dane o przeżyciach pochodzą z bazy danych EUROCARE.W analizie EUROCARE-4, która objęła 23 państwa europejskie, średni odsetek pięcioletnich przeżyć chorych na raka płuca, zdiagnozowanych w latach 1995-1999, wyniósł $10 \%$. Dla Polski był on niższy od średniej i wyniósł 8,2\% [4]. Według EUROCARE standaryzowane wskaźniki 5-letnich przeżyć względnych u pacjentów ze zdiagnozowanym rakiem płuca w latach 2000-2002 wynosiły 12\%. Podobny wskaźnik 5-letnich przeżyć - 11,5\% chorych zdiagnozowanych w Polsce w analogicznym okresie 2000-2002 uzyskano w pierwszej populacyjnej analizie przeżyć chorych na nowotwory przeprowadzonej przez Zakład Epidemiologii i Prewencji Nowotworów i Krajowy Rejestr Nowotworów Centrum Onkologii - Instytutu w Warszawie [5]. Co ciekawe, dla raka płuca (i raka wątroby) wartości wskaźników uzyskane w Polsce najmniej odbiegały od średnich europejskich (mniej niż o 1 punkt procentowy, przy maksymalnych różnicach dochodzących do 26 punktów procentowych dla czerniaka i nowotworów kości). Niestety, w badaniach epidemiologicznych nie ma oddzielnych danych dla lepiej rokującego raka niedrobnokomórkowego płuca i gorzej rokującego raka drobnokomórkowego płuca. 2-letnie przeżycia chorych na raka płuca wahają się w granicach 20-40\% dla pacjentów z postacią ograniczoną i poniżej $5 \%$ dla pacjentów z postacią uogólnioną, 5-letnie przeżycia odpowiednio 10-13\% i 1-2\% [6]. Przeżycia pacjentów leczonych w SP ZOZ MSW z W-MCO w Olsztynie w latach 2003-2006 mieściły się w powyższych granicach: 2-letnie przeżycia całkowite pacjentów z postacią ograniczoną DRP 
wynosiły 36\%, 5-letnie - 15\%, natomiast spośród pacjentów z postacią uogólnioną 2 lata przeżył tylko 1 pacjent, co stanowi 1,6\% (przeżycia tych ostatnich pacjentów były obliczane od rozpoczęcia paliatywnej radioterapii, a nie chemioterapii).

Rak drobnokomórkowy płuca jest nowotworem wrażliwym zarówno na chemioterapię, jak i na radioterapię. Odpowiedź na chemioterapię uzyskuje się u około 80\% leczonych, u większości chorych dochodzi jednak do progresji miejscowej i powstawania przerzutów odległych, w tym u ponad 50\% pacjentów - przerzutów do mózgu. Radioterapia raka płuca w postaci ograniczonej stosowana jest ze względu na częste nawroty lokoregionalne, sięgające $80 \%$, zmniejsza bowiem ryzyko nawrotu miejscowego o około $30 \%$ [7]. Metaanaliza opublikowana przez Pignona i wsp. w 1992 roku na podstawie 2103 chorych na drobnokomórkowego raka płuca w stadium LD wykazała znamienną korzyść z dodania radioterapii do leczenia systemowego - wzrost o 5,4\% odsetka przeżyć 3-letnich (z 8,9\% do 14,3\%) i zmniejszenie o 14\% ryzyka zgonu [8]. Obecnie standardem postępowania u chorych na drobnokomórkowego raka płuca w stadium LD jest radiochemioterapia. Dotychczas nie został jednoznacznie określony optymalny sposób kojarzenia chemioterapii i radioterapii. Przeprowadzono szereg badań mających na celu ustalenie sposobu kojarzenia radioterapii z chemioterapią, wyniki badań randomizowanych są jednak niejednoznaczne. Takada i wsp. wykazali, że zastosowanie radioterapii równocześnie $z$ chemioterapią zwiększa odsetek pacjentów przeżywających 2, 3 i 5 lat w porównaniu z pacjentami otrzymującymi radioterapię po zakończeniu chemioterapii [9]. Murray i wsp. wykazali zysk zarówno w przeżyciach całkowitych, jak i w przeżyciach wolnych od wznowy w grupie otrzymującej radioterapię równocześnie z 1 . kursem chemioterapii w stosunku do chorych leczonych radioterapią z ostatnim kursem chemioterapii [10]. Natomiast zysku takiego nie stwierdzono $\mathrm{w}$ innym randomizowanym badaniu porównującym radioterapię stosowaną z 1 . i z 6 . kursem chemioterapii [11]. W badaniu przeprowadzonym przez Jeremica i wsp. wykazano natomiast, iż pacjenci otrzymujący napromienianie równoczasowo z chemioterapią w 1-4 tygodniu od rozpoczęcia chemioterapii lepiej rokowali co do przeżyć 5-letnich w porównaniu z pacjentami napromienianymi w 6.-9. tygodniu od rozpoczęcia chemioterapii (30\% vs $15 \%, p=0,052$ ) [12]. Metaanalizy nie potwierdzają zysku wykazywanego w niektórych badaniach randomizowanych, ale widoczna jest pewna tendencja w poprawie przeżyć głównie 2-letnich w przypadku stosowania radioterapii z wcześniejszymi kursami chemioterapii, szczególnie przy zastosowaniu napromieniania 2 razy dziennie [11-14].

Przeprowadzono szereg analiz porównujących grupy pacjentów otrzymujących radiochemioterapię w różnym skojarzeniu (sekwencyjna vs równoczasowa) oraz grupy pacjentów rozpoczynających radioterapię z poszczególnymi cyklami chemioterapii (1-2 vs $3-4$ vs $5-6$ vs $3-6$ vs $1-3$ vs 4-6). Ze względu na mnogość przeprowadzonych analiz założono poprawkę Bonferroniego, uznając za znamienne statystycznie wartość $p \leq 0,001$. Analiza przeżyć pacjentów z postacią LD leczonych w tutejszym ośrodku wykazała tendencję do wydłużenia przeżyć 2-letnich w przypadku stosowania równoczasowej radiochemioterapii w porównaniu z leczonymi sekwencyjnie (2-letni OS odpowiednio 44\% i 31\%, mediana przeżyć odpowiednio 21 i 15,5 miesiąca; różnice nieznamienne). Natomiast różnice w przeżyciach 5-letnich nie występowały (5-letni OS odpowiednio 17\% i 16\%). Nie zaobserwowano różnic dotyczących przeżyć 2-letnich pomiędzy pacjentami, u których rozpoczynano radioterapię z 1. lub 2. kursem chemioterapii, i pacjentami, u których rozpoczynano radioterapię z 3.-6. kursem chemioterapii (2-letni OS odpowiednio 48\% i 42\%, mediana przeżyć odpowiednio 20 i 21 miesięcy). Zaobserwowano różnicę w całkowitych przeżyciach 5-letnich (5-letni OS odpowiednio 24\% i 14\%; różnica nieznamienna). Przeżycia całkowite zarówno 2-letnie, jak i 5-letnie były lepsze dla pacjentów otrzymujących radiochemioterapię równoczasową z 1. lub 2. kursem chemioterapii w stosunku do pacjentów leczonych sekwencyjnie (2-letni OS odpowiednio 48\% i 31\%, 5-letni OS odpowiednio 24\% i 16\%; różnice nieznamienne statystycznie).

Turrisi i wsp. wykazali znamienną poprawę przeżyć zarówno 2-letnich, jak i 5-letnich przy zastosowaniu równoczasowej radiochemioterapii z 1. kursem chemioterapii przy frakcjonacji 2 razy dziennie (2-letni OS odpowiednio 47\% i 41\%, 5-letni OS odpowiednio 26\% i 16\%, mediana przeżyć odpowiednio 23 i 19 miesięcy) [15]. W przypadku pacjentów leczonych w SP ZOZ MSW z W-MCO w Olsztynie w latach 2003-2006 nie zaobserwowano podobnych zależności (2-letni OS odpowiednio 40\% i 36\%, 5-letni OS odpowiednio 16\% i 19\%, mediana przeżyć 19 miesięcy dla obu sposobów frakcjonowania dawki). Należy podkreślić, że w badaniu Turrisiego dawka frakcjonowana konwencjonalnie wynosiła 45 Gy w 25 frakcjach, co prawdopodobnie jest dawką zbyt niską, pacjenci napromieniani raz dziennie w tutejszym ośrodku otrzymywali sumaryczną dawkę 50,4-59 Gy.

Wydaje się, iż szczególnie istotnym czynnikiem wpływającym na przeżycia całkowite pacjentów leczonych z intencją radykalną jest czas, jaki upływa od rozpoczęcia chemioterapii do zakończenia radioterapii. W metaanalizie obejmującej 8 badań III fazy uzyskano różnice w przeżyciach 5-letnich zależnie od tego czynnika [14].W grupach pacjentów, którzy zakończyli radioterapię w czasie nie dłuższym niż 30 dni od rozpoczęcia chemioterapii, uzyskiwano powyżej 20\% przeżyć 5-letnich. W przypadku dążenia do jak najwcześniejszego i jak najbardziej intensywnego leczenia napromienianiem pacjentów z DRP pojawia się szereg problemów, takich jak znaczne zwiększenie liczby i nasilenia 
ostrych odczynów popromiennych (szczególnie zapalenia przełyku), trudności w utrzymaniu reżimu chemioterapii, kłopoty natury organizacyjnej, co znacznie utrudnia takie postępowanie.

Na rokowanie w drobnokomórkowym raku płuca wpływa niewątpliwie płeć pacjenta. Przeżycia kobiet są lepsze niż mężczyzn (2-letni OS dla kobiet 29-35\% i 11-15\% dla mężczyzn) [16, 17]. Podobnie analiza dotycząca pacjentów leczonych w tutejszym ośrodku wykazała znamiennie lepsze przeżycia 2-letnie kobiet niż mężczyzn.

Przerzuty do ośrodkowego układu nerwowego rozwijają się u 50-65\% pacjentów chorych na DRP. Przeprowadzono szereg pozytywnych badań randomizowanych poświęconych roli PCI w zmniejszeniu odsetka występowania przerzutów do mózgu i poprawy przeżyć [18-20]. Metaanaliza obejmująca 7 badań (prawie 1000 pacjentów) potwierdziła wyniki badań randomizowanych [21]. Profilaktyczne napromienianie mózgu zmniejsza o 50\% ryzyko wystąpienia przerzutów do mózgu (do 25-35\%) oraz zwiększa udział 3-letnich przeżyć o 5,4\% (20,7\% vs $15,3 \%)$. W tutejszym ośrodku w latach 2003-2006 profilaktyczne napromienianie mózgu otrzymywali pacjenci w stadium LD, którzy osiągnęli całkowitą regresję choroby. Zaobserwowano lepsze przeżycia całkowite pacjentów, u których zastosowano $\mathrm{PCl}$, niż tych, u których takiego leczenia nie zastosowano (2-letni OS odpowiednio $58 \%$ i $21 \%$, 5 -letni OS odpowiednio $18 \%$ i 12\%, mediana przeżyć odpowiednio 27 i 11 miesięcy; różnice znamienne).

\section{Wnioski}

W porównaniu z leczeniem sekwencyjnym przeżycia chorych leczonych radykalnie (postać LD) były nieznamiennie dłuższe, jeżeli radioterapię stosowano jednoczasowo z chemioterapią. Zauważono również tendencję do poprawy przeżyć w przypadku kojarzenia radioterapii z chemioterapią na początku całego cyklu leczenia, chociaż różnice były odległe od znamienności statystycznej. Wyniki leczenia uzyskane w ciągu pierwszych 4 lat działalności ośrodka SP ZOZ MSW z W-MCO w Olsztynie nie odbiegały od publikowanych wyników badań klinicznych.

\section{Dr hab. n. med. Sergiusz Nawrocki}

Zakład i Oddział Radioterapii SP ZOZMSW z Warmińsko-Mazurskim Centrum Onkologii w Olsztynie Al. Wojska Polskiego 37, 10-228 Olsztyn e-mail:sergiusz@cyberia.pl

\section{Piśmiennictwo}

1. Raporty na podstawie danych Centrum Onkologii http://85.128.14. 124/krn/.

2. Spira A, Ettinger DS. Multidisciplinary management of lung cancer. NEngl J Med 2004; 350: 379-392.

3. Rzyman W. Rak płuca. Forum Medycyny Rodzinnej 2008; 2: 407-419.

4. http://www.eurocare.it/DatabaseEU4/tabid/78/Default.aspx.

5. Wojciechowska U, Didkowska J, Zatoński W. Pięcioletnie przeżycia chorych na nowotwory złośliwe w Polsce. Nowotwory J Oncol 2010; 60: 122-128.

6. Lally BE, Urbanic JJ, Blackstock AW i wsp. Small-cell lung cancer: have we made any progress over the last 25 years? Oncologist 2007; 12: 1096-1104.

7. Warde P, Payne D. Does thoracic irradiation improve survival and local control in limited-stage small-cell carcinoma of the lung? A meta-analysis. J Clin Oncol 1992; 10: 890-895.

8. Pignon JP, Arriagada R, Ihde DC i wsp. A meta-analysis of thoracic radiatiotherapy for small-cell lung cancer. NEng JMed 1992; 327: 1618-1624.

9. Takada M, Fukuoka M, Kawahara M i wsp. Phase III study of concurrent versus sequential thoracic radiotherapy in combination with cisplatin and etoposide for limited-stage small-cell lung cancer: results of the Japan Clinical Oncology Group Study 9104. J Clin Oncol 2002; 20: 3054-3060.

10. Murray N, Coy P, Pater JL i wsp. Importance of timing for thoracic irradiation in the combined modality treatment of limited-stage small-cell lung cancer. The National Cancer Institute of Canada Clinical Trials Group. J Clin Oncol 1993; 11: 336-344.

11. Spiro SG, James LE, Rudd RM i wsp. Early compared with late radiotherapy in combined modality treatment for limited disease small-cell lung cancer: A London Lung Cancer Group Multicenter Randomized Clinical Trial and meta-analysis. J Clin Oncol 2006; 24: 3823-3830.

12. Jeremic B, Shibamoto $Y$, Acimovic $L i$ wsp. Initial versus delayed accelerated hyperfractionated radiation therapy and concurrent chemotherapy in limited small-cell lung cancer: a randomized study. J Clin Oncol 1997; 15: 893-900.

13. Fried DB, James LE, Rudd RM i wsp. Early compared with late radiotherapy in combined modality treatment for limited disease small-cell lung cancer: A London Lung Cancer Group multicenter randomized clinical trial and meta-analysis. J Clin Oncol 2006; 24: 3823-3830.

14. De Ruysscher D, Pijls-Johannesma M, Bentzen SM i wsp. Time between the first day of chemotherapy and the last day of chest radiation is the most important predictor of survival in limited-disease small-cell lung cancer. J Clin Oncol 2006; 24: 1057-1063.

15. Turrisi AT, Kim K, Blum R i wsp. Twice-daily compared with once-daily thoracic radiotherapy in limited small-cell lung cancer treated concurrently with cisplatin and etoposide. NEngl J Med 1999; 340: 265-271.

16. Wolf M, Holle R, Hans K i wsp. Analysis of prognostic factors in 766 patients with small cell lung cancer (SCLC): The role of sex as a predictor for survival. Br J Cancer 1991; 63: 986-992.

17. Maurer LH, Pajak TF. Prognostic factors in small cell carcinoma of the lung: a cancer and leukemia group B study. Cancer Treat Rep 1981; 65: 767-774.

18. Gregor A, Cull A, Stephens RJ i wsp. Prophylactic cranial irradiation is indicated following complete response to induction therapy in small cell lung cancer: results of multicenter randomized trial. Eur $J$ Cancer 1997; 33: 1752-1758.

19. Arriagada R, Chevalier TLe, Rivière A i wsp. Patterns of failure after prophylactic cranial irradiation in small-cell lung cancer: analysis of 505 randomized patients. Ann Oncol 2002; 13: 748-754.

20. Slotman B, Faivre-Finn C, Kramer G i wsp. Prophylactic cranial irradiation in extensive small-cell lung cancer. N Engl J Med 2007; 357: 664-672.

21. Auperin A, Arriagada R, Pignon JP i wsp. Prophylactic cranial irradiation for patients with small-cell lung cancer in complete remission. Prophylactic Cranial Irradiation Overview Collaborative Group. N Engl J Med 1999; 341: 476-484. 